\title{
Pakistani Learners' Perceptions Regarding Mobile Assisted Language Learning in ESL Classroom
}

\author{
Muhammad Mooneeb Ali ${ }^{1 \& 2}$, Muhammad Asim Mahmood ${ }^{3}$, Muhammad Nadeem Anwar ${ }^{4}$, Lubna Akhlaq Khan ${ }^{4}$ \\ \& Adila Hussain ${ }^{5}$ \\ ${ }^{1}$ Department of Applied Linguistics Government College University Faisalabad, Pakistan \\ ${ }^{2}$ Lecturer English, H.E.D. Punjab, Pakistan \\ ${ }^{3}$ Dean Social sciences Government College University Faisalabad, Pakistan \\ ${ }^{4}$ Assistant professor H.E.D. Punjab, Pakistan \\ ${ }^{5}$ Lecturer English, University of the Punjab Gujranwala Campus, Pakistan \\ Correspondence: Muhammad Mooneeb Ali, Department of Applied Linguistics Government College University \\ Faisalabad, Pakistan. E-mail: mooneeebali@hotmail.com
}

Received: February 22, 2019 Accepted: May 6, 2019 Online Published: July 17, 2019

doi:10.5539/ijel.v9n4p386 URL: https://doi.org/10.5539/ijel.v9n4p386

\begin{abstract}
Technological advancement with its extensive use in every field of life has also impelled the educators to apply innovative techniques inside the classrooms. Mobile assisted language learning (here on wards MALL) is a latest technique which is gaining popularity. The current paper intends to explore the perceptions of Pakistani ESL learners on integrating MALL in English language classroom. The study used quantitative paradigm as research design. The population of the study comprised of Intermediate students, studying in public-sector colleges of Lahore. From the said population 60 students from 6 public sector colleges in Lahore were selected through simple random sampling. The data were congregated through a close-ended questionnaire. The collected data were later analyzed with the help of SPSS. The results illustrated that the Pakistani students have shown positive inclination towards MALL usage inside the ESL classrooms. The study also highlights another feature of MALL that it not only supports learning with ease and comfort but also motivates learners to learn in a collaborative ambiance. If MALL can be implemented intelligently in Pakistani classrooms it can be an influential tool for language learning.
\end{abstract}

Keywords: Mobile assisted Language learning (MALL), English as second language (ESL), perceptions, ESL learner, Pakistan

\section{Introduction}

The recent advancements in science and technology have brought attitudinal and behavioral changes in the people of this age. Newly invented technological tools have been facilitating the people in different ways. These gadgets have helped people in completing their official assignments, in performing their daily routine activities, and in enjoying their leisurely hours. Moreover, these tools have also improved the condition of individuals by serving them in every field of life. In other words, by conquering almost every field of life from engineering to agriculture and from construction to mechanics technology has brought about a healthy change in the life of people.

Similarly, technology has revolutionized the field of education. In developed countries the use of technology in educational institutions in general and in classrooms in particular is becoming a regular practice. Now no classroom is devoid of technological tools. Some common technological tools used inside the classrooms are multimedia, OHP, computers and smart boards. Other important tools used in the classrooms are the mobile phones/devices which are gaining popularity amongst the educators and the students. Mobile phones were made for communication only but later on with the invention of Android technology, internet feature; emailing, social networking has changed the overall use of mobile phones. Now one can say that mobile phones are replicating computers in their efficiency level. All these characteristics of mobile phones have made them indispensible in the world of today (Evans-Cowley, 2010)

\subsection{Mobile Assisted Language Learning (MALL)}

Mobile assisted language learning (MALL) can be taken as the invasion of the mobile technology in the learning 
process of languages. The mobility, accessibility and the practicality of the mobile technology are the key component that can create this type of situation in class room for learning purposes. Huang et al. (as cited in Viberg \& Gronlund, 2012) stated that the preference of Mobile phones is due to their cheapness in price, smaller size, attractiveness for user, user friendly, and quality of being flexible. Any learning of language that takes place under the umbrella of these devices can be called mobile assisted language learning.

MALL is quite different from CALL (computerized assisted language learning) in its usage i.e., either personal or public, individual or collective which helps in opening new avenues of learning focusing upon the persistence and extempore of the accessibility and connectivity amongst multiple contextual usage (Kukulska-Hulme \& Shield, 2008). One can say that in language learning process mobile technology can be a helpful tool (Rosell-Aguilar, 2007; Fallahkhair, Pemberton, \& Griffiths, 2007), and others like (e.g., Chen \& Chang, 2011; Chang \& Hsu, 2011), says that these tools can help in motivating the learners for language learning. Similarly, scholar like Huang, Huang, Huang and Lin (2012), are of the view that MALL is supportive medium for language learning with technology. Another feature of MALL is that it also supports students in interacting with other learners by making collaborative groups and constructing different ways of learning (Joseph \& Uther, 2009).

\subsection{MALL Inside the Classrooms of Pakistan}

In Pakistan, no one denies the value of English as it is being taught at different stages and on multiple levels. Here the colonized affect has deeply upgraded the value of English. So English is taken as the most important language in Pakistani society. Abbas Alam and Rana (2011) claimed that the flavor of colonization was a geographical factor but their language (English) is still influential. From the sections of Arts and Humanities to Sciences and Applied Sciences all the syllabus is written in English. Similarly, the mode of study in all subjects lied under these disciplines is English. Pakistan is an ESL country where students' 1st language is Urdu so they find it extremely difficult to learn English. Here, the ways of teaching are so orthodox that the students hardly find interest in learning English. The public sector institutions have given some facilities to their students yet they are unable to introduce latest and innovative teaching methods dipped in technology to teach students differently and effectively. That's why Mahmood et al. (2014) had to claim that there is still need to introduce information and communication technology in the teaching of English in Pakistan.

\subsection{Statement of the Problem}

The steps taken by the government have helped promote information and communication technology (ICT) and mobile assisted language learning (MALL) in public-sector colleges of Punjab (Pakistan) recently. The government has distributed laptops among a large number of students. It has also provided WIFI facility to all public-sector colleges of Punjab. The students of public-sector colleges, through internet, can have access to the information present on internet through mobiles or laptops. There is an ever-growing trend in around the globe generally and in Pakistan specifically that everybody, including teachers and students, has his personal mobile phone. In fact, mobile devices have become integrated with daily lives through the process of domestication (Ling \& Donner, 2009).

As far as the investigations in language learning through MALL are concerned a number of researchers have been investigating its efficacy through experiments. The studies in this regard include Chen and Hsu (2008), Thornton and Houser (2003), Baleghzadeh and Oladrostam (2010), Zaki and Yunus (2015), Siddique (2015), Ali, Gulzar and Anwar (2018) etc. Adding to it, the studies like Kim, Ruecker and Kim (2017), Azli, Shah and Mohamad (2018), Nino (2014), Dehkordi and Taki (2018), and Oz (2014) investigated the perceptions towards MALL in different contexts. However, there are lesser studies investigating Pakistani ESL learners towards MALL. Considering limited number of MALL studies, the current study attempts to investigate perceptions of Pakistani ESL learners towards MALL usage in Public sector colleges of Lahore, Punjab.

\subsection{Research Objectives}

- To explore the perceptions of the students of Public sector colleges of Lahore about MALL

\subsection{Significance of the Study}

MALL is a new phenomenon in Pakistani context. Here mobile technology is not used for teaching and learning purposes. This study will be useful in finding out that if Mobile technology in Pakistani class rooms helpful or not? This study has theoretical and pragmatic significance. The results of this study will be helpful in determining the direction for public-sector colleges to introduce latest trends in learning for Pakistani learners. 


\subsection{Theoretical Framework}

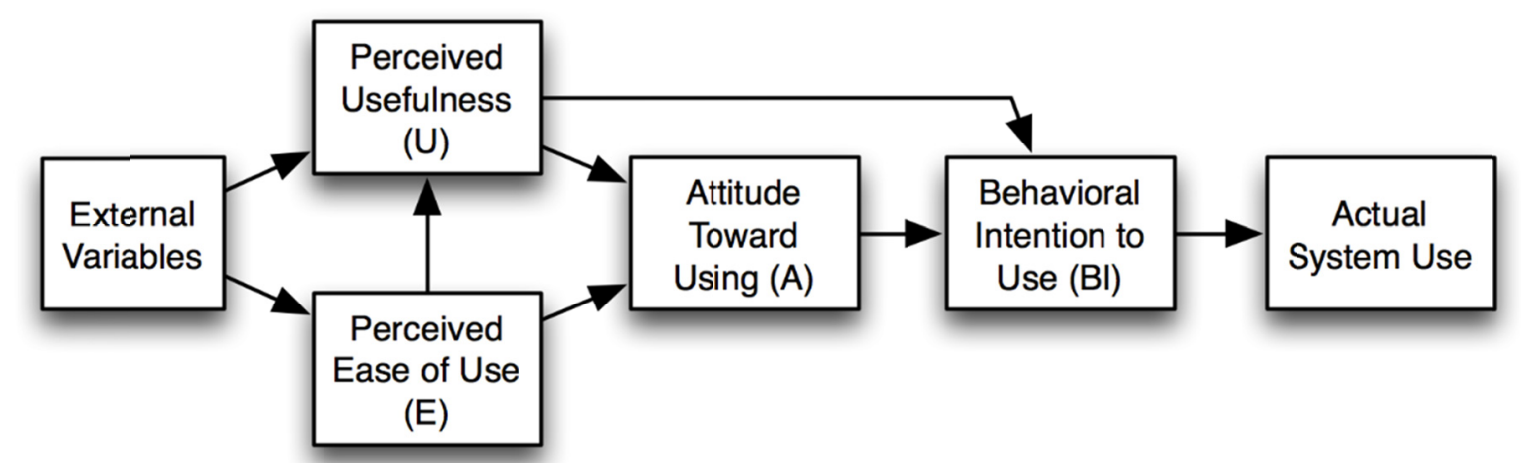

Figure 1. Theoretical framework

Technology Acceptance Model (TAM) has its origin in the theory of reasoned action which is baseline of the attitudes, beliefs, behaviors and intentions the persons individually (Sandberg \& Wahlberg, 2007). An efficiency of any person in any specific task is related to his attitude and behavior (Moss et al., 2010). Johnson (2005) stated. The external variables like age, experience, education and gender are directly connected with the perceived ease of use and perceived utility of the person regarding the acceptance of technology.

Technology acceptance model has been investigated and accepted by several researchers in different areas like conducting a web-based information system (van der Heijden, 2003) or applying it on the internet banking (Wang et al., 2003) as well as E commerce (Henderson \& Divett, 2003). Earlier researchers explain that TAM integration in a research which is based upon technology is accepted on a wider scale because of its usefulness and affectivity as a model.

In education Teo et al. (2008) stated that TAM has been applied in tools used inside the class. Lu et al. (2003) already applied the model for investigating attitudes towards Computer Assisted Language Learning (CALL) in ESL contexts similarly in MALL TAM has been one of the most widely used model. The constructs of TAM are important and it is pivotal to find out their implications to understand the students' attitudes while using MALL to improve their English language learning of these constructs to this research context is that it is important to examine the learners' perceptions of using M-learning in improving their English learning.

\section{Literature Review}

According to Gangaiamaran and Psupathi (2017), mobile assisted language learning is considered as the subdivision of mobile learning (M-learning) and computer-assisted language learning (CALL). The current study uses the term MALL as its area of investigation.

Mobile-assisted language learning has been defined by various researchers. Miangah and nezarat (2012) define MALL as the use of mobile technology in language learning. In contrast to classroom learning, in MALL there is no need for the learners to sit in a classroom or at a computer to get learning materials. Pachler, Bachmair and Cook (2010) consider MALL as a process of coming to know and being able to operate successfully in, and across, new and ever-changing contexts and learning spaces with an emphasis on understanding and knowing how to utilize our everyday life-worlds as learning spaces. Sharples (2005) states that MALL can be taken as a means to understand the communication amongst different situations of persons and communicative technologies. However, if learning process happens via or with mobile device away from traditional learning environment, then is Mobile assisted language learning.

Mobile assisted language learning consists of different devices from android phones to smart phones, e books and palm tops etc. (Burston, 2013). Kukulska-Hulme and Shield (2008) is of the view that mobile assisted language learning is quite different from computerized assisted language because of the usage of portable, personal devices which helps in finding out new avenues and methods of learning focusing and stressing upon the contextual aspect focused on learning.

The invasion of Mobile technology for language learning purpose allows the users to not only use different methods for learning other subjects but also help to learn language willfully. While highlighting the advantages of MALL Colpaert (2004) argues that this type of learning helps create such a learning ambiance as provide learners with an opportunity to have face to face interaction. Secondly distance learning through mobile technology can 
also be made possible. Online learning is also an important method for learning through mobile. Mobile MALL's effectiveness has been increasing since its introduction and there are many relevant researches which proved the efficiency of MALL as an impactful learning tool. Chen and Hsu (2008) viewed that there is a dire need to revisit the teaching methods as MALL is an important aspect of students' life and the ways of learning are affecting by its inclusion. Thornton and Houser (2003) explored that energetic and young students gave preference to MALL rather than conventional learning methods. Chen and Hsu (2008) investigated in Taiwan that MALL impacts positively on vocabulary learning of the students as the learners became motivated to learn in flexible environment. Baleghzadeh and Oladrostam (2010) found out that MALL has a positive influence on the grammar of ESL learners. Zaki and Yunus (2015) investigated that writing skills of the students were improved when they learnt through MALL. Siddique (2015) in Pakistani context found out the efficiency of MALL for the betterment of writing skills. Hence, the above-mentioned studies establish the efficacy of MALL for teaching and learning language purposes.

\subsection{Related Studies}

Another direction in the field is extracting MALL related insight out of the minds of the participants which is done through perception-based investigations. Kim, Ruecker and Kim (2017) investigated the benefits of learning with mobile technology for TESOL students. It also aimed to explore their perceptions of learning with this type of technology. The study was conducted by using mixed method approach. The samples of the study were TESOL students. Three instruments were used to collect both qualitative and quantitative data. These instruments were a pre-study survey, students' reflection for each class project and a post study survey. The study recommended effective instructional strategies, training of professional workshop development, and ongoing technical support and assistance.

Azli, Shah and Mohamad (2018) investigated the perception on the usage of MALL in English as a Second Language (ESL) among private vocational college students. Data were collected through a survey questionnaire adapted from Techonology Acceptance Model (TAM). The results revealed that respondents had positive perception on the usage of MALL. Majority of the respondents showed overall agreement on both constructs perceived usefulness (PU) and perceived ease of use (PEoU) of MALL. They believed the usage of MALL will enhance the teaching and learning process.

Nino (2014) conducted a perception-based study on 286 university students. The study aimed at finding the use of mobile applications for independent language learning in higher education. It also attempted to know how learners use mobile apps in line with their class to enhance their learning experience. The study used survey design. The analyzed data suggested that MALL is suitable for passive language skills such as vocabulary acquisition, written and oral comprehension, pronunciation, vocabulary and grammar practice in particular. The responses of the students also highlighted the advantages of the use of mobile apps for language learning which include convenience, use of authentic resources, offer immediate feedback and several opportunities to personalize authentic language practice.

Dehkordi and Taki (2018) have recently investigated the perception of 90 Iranian EFL learners toward the use of mobile-assisted language learning. The objective of the study was to highlight the difference between the mobile learning perceptions of Iranian male and female EFL learners. It also attempted to know the difference between the mobile learning adequacies of Iranian male and female EFL learners. In order to meet the objectives, 90 male and female EFL learners of different proficiency levels were selected as sample of the study. The instrument utilized in the study was Mobile Learning Perception Scale developed by Uzunboylu and Ozdamli (2011). Two independent $\mathrm{T}$ tests were performed to determine the difference between male and female participants. The results claimed that although, the perception of male learners was slightly more than more than female learners, it failed to be statistically significant. Therefore, there is no significant difference between Iranian male and female learners' mobile learning perception and first null hypothesis was accepted. So was the case with second hypothesis which was related to adequacy of mobile learning perception. However, both male and female learners had a positive view towards e-learning and technology-based language learning.

Another study about perception of MALL was done by Oz (2014). The researcher attempted investigate pre-service EFL teachers' perception about MALL and find out whether their perception differed by gender, grade level and grade point average (GPA). The study also tried to determine whether gender, grade level, and GPA would predict their perception of MALL. Quantitative research design was adopted. A total of 201 participants enrolled in an EFL teacher education department at a major state university participated in the study and completed the "Mobile Learing Perception Scale". The data revealed that overall the participants had high levels of perceptions about MALL. It also explored that gender, grades and GPA differences moderated the effects of 
measured constructs on their perceptions of MALL. The data suggested positive attitude towards using mobile devices in language instruction.

Haider (2013) investigated about, perceptions of ESL Intermediate college teachers towards Computer Assisted Language Learning (CALL), evocative research study was carried out with ESL teachers working at different Intermediate colleges who were using computers in their teaching. The study used mixed method approach. A sample of 10 teachers participated in the study. The data were collected through a questionnaire. Adding to it, semi-structured interviews were recorded and transcribed. The results revealed teachers' perceived computer competence, general perceptions towards CALL and their implementation of CALL in class. The study also revealed that perceptions of teachers towards CALL are usually positive and most of the teachers are aware of the advantages of CALL.

Ali, Nazir and Rehman (2016) attempted to investigate the usage of MALL on Pakistani college students. The study utilized quantitative paradigm as research design. Through a five-point likert scale questionnaire college students' perceptions regarding the efficacy of MALL were recorded. The results suggested that MALL might support learning of EFL students. They might feel confident when they learnt English through mobile technology. The study also recommended that Pakistani classrooms with MALL might help create a congenial atmosphere for learning English language.

Hence, the studies like Kim, Ruecker and Kim (2017), Azli, Shah and Mohamad (2018), Nino (2014), Dehkordi and Taki (2018), and Oz (2014) investigated the perceptions towards MALL in different contexts. However, studies investigating perceptions towards MALL in Pakistani context, where MALL is a novice phenomenon, are perhaps not large in number. Haider (2013) and Ali, Nazir and Remham (2016) are among the few studies conducted in Pakistani context. The former relates to perceptions towards CALL while the latter is about MALL yet its sample size was very limited. Moreover, there is not a single study which has investigated participants' perception through the framework of TAM. So, for better understanding of the phenomenon a research study deems necessary.

\section{Methods}

In order to meet the objective of the study i.e. the perceptions of participants about MALL, quantitative research paradigm with descriptive research design seems appropriate as this type or research design aims to specify or describe naturally occurring phenomenon without experimental manipulation (Seliger \& Shohamy, 1989). Such type of research tends to construct statistical models and figures to explain what is observed and makes use of tools such as questionnaire, surveys, measurements and other equipment to collect numerical or measurable data (Dornyei \& Taguchi, 2010).

\subsection{Participants}

MALL as a concept is unused in Pakistan but it is not unheard by students and teachers. The population for the current study was the Intermediate students studying in public sector colleges of Lahore in Pakistan. To delimit the study from all the colleges in Lahore, only 6 public sector colleges were selected through convenient sampling technique. Furthermore, from these 6 colleges only 60 students, 10 from each college were chosen as a sample of the study using simple random sampling method. This delimitation was done to build up the authenticity and validity of the research.

\subsection{Instrument}

The instrument used for the current study was a close-ended questionnaire. This questionnaire was adapted from the studies conducted by Azli, Shah and Mohamad (2018) and Alhassan (2016). This questionnaire was contextualized to Pakistani context after slight modification. 60 Students filled the questionnaire which was comprised of 11 questions. The constructs of the questionnaire were on Likert scale which can be explained as a scale of psychometric replies which is often utilized in questionnaires for the purpose of obtaining the preference or an acceptance or agreement degree towards a question's statement (Bertram, 2007).

\section{Results}

The data obtained through the questionnaire were statistically analyzed with the help of SPSS. The overall findings of the questionnaire have been presented in terms of two sections i.e., (a) reliability and validity and (b) frequency of constructs. 


\subsection{Reliability and Validity}

Table 1(a). Case processing summary

\begin{tabular}{llll}
\hline \multicolumn{2}{l}{ Case Processing Summary } & \\
\hline Cases & & $\mathrm{N}$ & $\%$ \\
& Valid $^{2}$ & 60 & 100.0 \\
& Excluded $^{\mathrm{a}}$ & 0 & .0 \\
& Total & 60 & 100.0 \\
\hline
\end{tabular}

Note. a. Listwise deletion based on all variables in the procedure.

Table 1(b). Reliability statistics

\begin{tabular}{ll}
\hline Reliability Statistics & \\
\hline Cronbach's Alpha & N of Items \\
.805 & 22 \\
\hline
\end{tabular}

The reliability statistic of the questionnaire is reflected in the above Table 1. It can be seen that the Cronbach Alpha's value is .805 which validates the fact that the questionnaire is reliable and valid.

\subsection{Frequency Tables of Questions}

Table 2. Q1. My mobile device is easy to handle and portable

\begin{tabular}{llllll}
\hline & & Frequency & Percent & Valid Percent & Cumulative Percent \\
\hline Valid & Neutral & 12 & 20.0 & 20.0 & 20.0 \\
& Agree & 20 & 33.3 & 33.3 & 53.3 \\
& Strongly Agree & 28 & 46.7 & 46.7 & 100.0 \\
& Total & 60 & 100.0 & 100.0 & \\
\hline
\end{tabular}

As shown in Table 2, the respondents express their inclination or disagreement towards the statement of the question. Out of 60 participants of this study majority of the students validate this statement that mobile device is user friendly and can be handled easily. Another aspect is the portability of mobile device which actually is the most important feature of mobile devices. The cumulative percentage of agree and strongly agree is $80 \%$ which is quite high. This also narrates the viewpoint that presently mobile devices are accepted and used by the people and students. However, it can be viewed from the above table that there are no students who are against or strongly against this feature of mobile device.

Table 3. Q2. I prefer Language learning through Mobile devices than computers

\begin{tabular}{llllll}
\hline & Frequency & Percent & Valid Percent & Cumulative Percent \\
\hline Valid & Stronlgy disagree & 2 & 3.3 & 3.3 & 3.3 \\
& Neutral & 10 & 16.7 & 16.7 & 20.0 \\
& Agree & 17 & 28.3 & 28.3 & 48.3 \\
& Stronlgy agree & 31 & 51.7 & 51.7 & 100.0 \\
& Total & 60 & 100.0 & 100.0 & \\
\hline
\end{tabular}

Table 3 reveals that the students have given their opinion in favor of using mobile device in their academics and especially for language learning purposes. Looking at the Table 1 can see that considerable percentage of participants i.e., almost $80 \%$ are in favor of using mobile phones for language learning purpose as compared to computers. Whereas only $19 \%$ respondents are confused as they found mobile phones equally valuable and preference as compared to computers. Only $1 \%$ of the students are strongly disagreeing and they believe that using computers for language learning purposes is much better in effective learning as compared to mobile phones and mobile devices. 
Table 4. Q3. Learning Language through Mobile devices facilitates learning by providing anywhere any time learning facility

\begin{tabular}{llllll}
\hline & Frequency & Percent & Valid Percent & Cumulative Percent \\
\hline Valid & Neutral & 15 & 25.0 & 25.0 & 25.0 \\
& Agree & 20 & 33.3 & 33.3 & 58.3 \\
& Strongly agree & 25 & 41.7 & 41.7 & 100.0 \\
& Total & 60 & 100.0 & 100.0 & \\
\hline
\end{tabular}

Table 4 shows that $75 \%$ of the respondents cumulatively accept the value of ubiquitous learning. Ubiquitous learning is a phenomenon about learning everyday anywhere and anytime. On contrary there are no students in the population who disagreed or strongly gave their verdict against the utility of mobile devices for language learning purposes without time and place restriction. Only $25 \%$ students remained neutral which itself suggested that they were not rejecting the utility of mobile device but might be there were other factors like internet connection, noisy environment, settled with the conventional mode of learning languages or difficulty in adjusting to the new language learning method etc. they thought that mobile devices were not facilitating them to learn language outside.

Table 5. Q4. I utilize various language softwares as supportive materials through my mobile device.

\begin{tabular}{|c|c|c|c|c|c|}
\hline & & Frequency & Percent & Valid Percent & Cumulative Percent \\
\hline \multirow[t]{4}{*}{ Valid } & Neutral & 14 & 23.3 & 23.3 & 23.3 \\
\hline & Agree & 17 & 28.3 & 28.3 & 51.7 \\
\hline & Strongly agree & 29 & 48.3 & 48.3 & 100.0 \\
\hline & Total & 60 & 100.0 & 100.0 & \\
\hline
\end{tabular}

Table 5 indicates that $76.6 \%$ of the samples support the trend that they utilize different types of language softwares that can assist them in their conventional learning. Only $23.3 \%$ respondents remain neutral. This may be due to the fact that Pakistani students have not been previously learning through mobile devices and as MALL is in its initial phases so the common, latest and different techniques, softwares that provided aiding materials have been unknown to them. It is important that there is no one who rejects that they cannot utilize their mobile devices to download different softwares that can help them to learn language commendably.

Table 6. Q5. The process of Language learning through Mobile devices motivates me to learn.

\begin{tabular}{llllll}
\hline & Frequency & Percent & Valid Percent & Cumulative Percent \\
\hline Valid & Strongly disagree & 2 & 3.3 & 3.3 & 3.3 \\
& Disagree & 2 & 3.3 & 3.3 & 6.7 \\
& Neutral & 11 & 18.3 & 18.3 & 25.0 \\
& Agree & 17 & 28.3 & 28.3 & 53.3 \\
& Strongly agree & 28 & 46.7 & 46.7 & 100.0 \\
& Total & 60 & 100.0 & 100.0 & \\
\hline
\end{tabular}

According to Table 6 majority of the respondents i.e., 75\% (cumulative percentage of agree and strongly agree) state they are motivated and feel confident in the process of learning language through mobile phones. However, there are almost $18 \%$ respondents who remain indecisive about finding out MALL as a motivational factor also. They are still confused to explore either MALL encourages them to learn language or not. There are almost $6 \%$ respondents who state that MALL has nothing to do with the motivation as they have not found any encouragement in themselves regarding learning language through mobile devices.

Table 7. Q6. My academic communication with the teacher is more effective on mobile devices

\begin{tabular}{llllll}
\hline & Frequency & Percent & Valid Percent & Cumulative Percent \\
\hline Valid & Strongly disagree & 5 & 8.3 & 8.3 & 8.3 \\
& Disagree & 4 & 6.7 & 6.7 & 15.0 \\
& Neutral & 6 & 10.0 & 10.0 & 25.0 \\
& Agree & 13 & 21.7 & 21.7 & 46.7 \\
& Strongly agree & 32 & 53.3 & 53.3 & 100.0 \\
& Total & 60 & 100.0 & 100.0 & \\
\hline
\end{tabular}


According to Table 7,75\% respondents support the statement that the use of MALL can improve the communication between teacher and the students. Importantly there are a few respondents almost $10 \%$ who are not clear about the improvement of their academic communication with their teacher. On the other hand, $15 \%$ of the participants oppose this feature as they may prefer face to face communication as compared to mobile conversation.

Table 8. Q7. I feel uncomfortable to use mobile device inside and outside the classroom

\begin{tabular}{llllll}
\hline & & Frequency & Percent & Valid Percent & Cumulative Percent \\
\hline Valid & Strongly disagree & 30 & 50 & 50 & 50 \\
& Disagree & 22 & 36.7 & 36.7 & 86.7 \\
& Neutral & 7 & 11.6 & 11.6 & 98.3 \\
& Strongly Agree & 1 & 1.7 & 1.7 & 100.0 \\
& Total & 60 & 100.0 & 100.0 & \\
\hline
\end{tabular}

The significant result of Table 8 is that almost $87 \%$ respondents disagree and state that they are comfortable and feel convenient to use mobile device inside and outside the language classrooms. Almost 11\% are uncertain about the comfort level of MALL in and outside class and only $1 \%$ student strongly disagreed and showed his displeasure claiming that use of mobile devices disturb them in and outside the language classrooms. This may be because that these students are habitual of following old methodologies for learning.

Table 9. Q8. I am unwilling to use mobile device academically.

\begin{tabular}{llllll}
\hline & & Frequency & Percent & Valid Percent & Cumulative Percent \\
\hline Valid & Strongly disagree & 19 & 31.7 & 31.7 & 31.7 \\
& Disagree & 33 & 55.0 & 55.0 & 86.7 \\
& Neutral & 8 & 13.3 & 13.3 & 100.0 \\
& Total & 60 & 100.0 & 100.0 & \\
\hline
\end{tabular}

Table 9 indicate the strong verdict in favor of using MALL i.e., 86.7\% respondents oppose the statement of this question and show their strong willingness to use mobile device for learning in an academic manner. Importantly there is no student who has shown displeasure to use MALL in academic context. There is zero percentage of students who are agreeing to the aspect that they are unwilling to use their mobile devices academically. However, there are only $12.3 \%$ students who remained neutral. This strong percentage of this population clearly reflects that Pakistan students are also eager and keen to use mobile devices in a different way for educational purposes.

Table 10. Q9. I prefer printed material rather than mobile devices for language learning

\begin{tabular}{llllll}
\hline & Frequency & Percent & Valid Percent & Cumulative Percent \\
\hline Valid & Strongly disagree & 29 & 48.3 & 48.3 & 48.3 \\
& Disagree & 25 & 41.7 & 41.7 & 90.0 \\
& Neutral & 5 & 8.3 & 8.3 & 98.3 \\
& Strongly agree & 1 & 1.7 & 1.7 & 100.0 \\
& Total & 60 & 100.0 & 100.0 & \\
\hline
\end{tabular}

Table 10 shows that $48.3 \%$ students strongly agreed, 41.7 agreed and only 8.3 are neutral to the construct. It is also worth mentioning here that only $1.7 \%$ students are disagreeing stating that they prefer printed material as compared to MALL. This clearly reflects that in colleges the concept of learning and gaining knowledge through different and relevant e-books, journals, magazines and other supporting materials is gaining popularity.

Table 11. Q10. Touch screens of mobile devices is inconvenient in learning

\begin{tabular}{llllll}
\hline & Frequency & Percent & Valid Percent & Cumulative Percent \\
\hline Valid & Strongly disagree & 24 & 40.0 & 40.0 & 40.0 \\
& Disagree & 30 & 50.0 & 50.0 & 90.0 \\
& Neutral & 5 & 8.3 & 8.3 & 98.3 \\
& Strongly agree & 1 & 1.7 & 1.7 & 100.0 \\
& Total & 60 & 100.0 & 100.0 & \\
\hline
\end{tabular}


Table 11 clearly suggests that respondents find touch-screen mobiles convenient and easier in the learning process and they appreciate to use touch-screen mobile for language learning. $90 \%$ students suggest that touch-screen interface is comfortable to them during learning language through their mobile phones. Only $8.3 \%$ remain neutral and $1.3 \%$ strongly agree that touch screen gives inconvenience while language learning process. This may be due to the reason that they are new touch-screen mobile users or they have mobile phones in which touch-screen does not work efficiently. It may also be so because the overall mobile phone is slow because of processor quality which also affects the touch system.

Table 12. Q11. I don't take learning seriously on my mobile device

\begin{tabular}{llllll}
\hline & Frequency & Percent & Valid Percent & Cumulative Percent \\
\hline Valid & Strongly disagree & 29 & 48.3 & 48.3 & 48.3 \\
& Disagree & 24 & 40.0 & 40.0 & 88.3 \\
& Neutral & 6 & 10.0 & 10.0 & 98.3 \\
& Agree & 1 & 1.7 & 1.7 & 100.0 \\
& Total & 60 & 100.0 & 100.0 & \\
\hline
\end{tabular}

Table 12 suggests that $88.3 \%$ students state that the concept of MALL has been taken quite seriously by them and the use of mobile phones for language learning purpose, though was for the first time for them yet whatever tasks, methods, techniques and other processes were involved in this type of learning was considered seriously and followed up by the students. $10.3 \%$ students remained neutral; they might be taking more time to adjust themselves to MALL. Whereas only $1.3 \%$ agreed with the statement that learning through the use of mobile phones is not a serious activity for them and they do not consider it a serious scenario.

\section{Discussion}

The current study aimed at exploring the perceptions of Pakistani ESL students regarding the use of MALL in classroom. For this particular purpose the researchers chose to use technology acceptance model as a framework. There are two important components of Technology acceptance model namely perceived usefulness (PU) and perceived ease of use (PeoU). Viewing perceived ease of use in the light of questions asked it can be said that the students in Pakistan agree with Shield and Kukulska (2008) who are of the opinion that mobile phones are perfect in their use and are extremely beneficial in language learning process as they allow the students to move freely and this has been the main reason of increase in use of mobile phones. Students and educationists are inclined towards mobile phones for language learning purposes because of its accessibility and mobility.

Stockwell (2007) stated that computers are less preferred by the students as mobile phones are convenient and sophisticated in the process of language learning. The major features of MALL are that it is spontaneous, ubiquitous and personalized as well Huang et al. (2012), But as compared to computers the user feels freedom of place as well as time and it is a great advantage for second language learners (Miangah \& Nezarat, 2012).

Similarly, if one talks about perceived usefulness of the MALL it can be seen that MALL motivates students. Motivation is an important aspect in the language learning process. Garrison and Anderson (2003) laid stress upon the value of motivation in education. It is a known fact that the role of motivation in learning as well as teaching is vital and has been proved in different studies (Pintrich \& Schunk, 2002). Huang, Hwang and Shadiev (2014) conducted a study which compared two groups it was found out that a group using MALL tools was superior in motivation and performance as to the other one.

Kukulska-Hulme (2009) stated MALL attracts students as it supports beyond classroom and inside classroom activities better than any other way of teaching and learning. These activities can blend practical and experiences with the technology. Further because of so many social and interactive functional features like communication, application organization, mobility, accessibility, connectivity, entertainment, infotainment blended with learning has made students more attracted towards MALL (Trinder, 2005). That is why McKinsey (2017) found out that MALL is gaining popularity and rise and it is a current trend of the world.

Another important aspect of MALL is that it provides a chance of group discussion virtually through mobile phones which allow users to discuss freely without any pressure of time. Importantly they can rely to any of the query whenever and wherever convenient. Pakistani students are also largely inclined towards discussing though mobile phones in groups as it allows easy interaction and communication without the fear of monitoring by the teacher. The students can easily exchange ideas and can develop learning strategies and solve issues related to learning (Bicen, 2015). According to Palalas (2011) due to these facilities and features of MALL the students are 
attracted to participate in the language learning activities as compared to conventional methods. That is why mobile phones are rated much higher and are now a usual part of the educational system.

MALL also provide autonomy to its learners as in the current era the growth of knowledge and rapid acceleration in the technology has urged to engage the learners in lifelong learning experiences, for any successful lifelong learning autonomy on the part of learner is very important as learners can control their pace of learning (Benson, 2011). This is a chief advantage of MALL that it provides independence to the learners and Pakistani students also are of the view that MALL provided them independence and freedom to learn according to their own pace and willingness related to context and ambiance. This argument of Pakistani students is also similar to the study conducted by Hazaea and Alzubi (2018), who found out that the feeling of autonomy was increased amongst learners during their learning process.

Overall it was found out that the learners in Pakistan took learning as a serious process through MALL and they hugely perceive that English language learning can improve immensely by the use and implementation of MALL in their language classrooms. The students here in Pakistan are also of the view that MALL enhances the affectivity of learning and integrating MALL provides an opportunity to learn seriously and vigorously by accessing various relevant materials and resources online and especially communicating with teachers and peers in groups where only serious discussion is allowed (Azli, Shah, \& Mohamad, 2018). So overall the student gave their opinions which reflect strong preference towards the perceived usefulness and perceived ease of use towards MALL and various questions and their replies clearly suggest that Pakistani students perceive that MALL is extremely relevant and useful as it provided various benefits and opportunities for learning.

\section{Conclusion}

Conclusively, the current study suggests that Pakistani ESL learners have strong and positive conviction regarding MALL and they perceive its role in changing and improving the ambiance and process of learning in Pakistan. The incorporation of MALL in Pakistani language classes provided a chance to the students to have access to different and useful learning materials and activities through internet regarding their learning problems. It also provided them with a new method of learning and assisted them to communicate and interact with their teachers and peers in groups. MALL aided the students to have conducive and favorable ambiance for learning while replacing the traditional learning styles. This latest learning method also made the students more interested and they became more attracted towards studies.

The results also show that there is a need to redesign the ways and methods of learning in Pakistani classrooms as they lack technology. They usually follow orthodox methods. So, the inclusion of MALL will be cheaper yet effective to produce quality results for the teachers and students as well. The flexibility of space and time will permit students to be relaxed yet attentive in their performances and it will also make the process of learning and monitoring easier. (Surina \& Kamaruzaman, 2009) indicated that the teachers should promote the use of MALL. So, looking at the context of MALL's importance its implementation is extremely important in this technology world (Buckenmayer, 2011) where different aspects of technology are exploited for benefiting mankind. Especially the use of MALL can bring positive changes in the performance of learning by flourishing new and revolutionary opportunities that can develop latest pedagogical methods in learning. These latest scaffoldings will make learning of language possible beyond restriction of place and time while helping the students to improve their motivation and participation and thus creating a student-centered ambiance (Tayan, 2017).

The study was delimited only to 6 public sector colleges ignoring other public as well as private sector colleges owing to lack of resources and time. As public-sector colleges are offering various programs of study. Only Intermediate students were chosen for data collection because it would be insightful to know whether learners at this stage were accepting technology or not, if accepting what were their perceived ideas about MALL. Future researchers may replicate the same study with larger number of samples. Studies aiming at exploring EFL learners' attitude towards MALL can also be conducted.

\section{References}

Abbas, F., Aslam, S., \& Rana, A. M. K. (2011). Code-mixing as a communicative strategy among the university level students in Pakistan. Language in India, 11(1), 95-108.

Alhassan, R. (2016). Mobile learning as a method of ubiquitous learning: Students' attitudes, readiness, and possible barriers to implementation in higher education. Journal of Education and Learning, 5(1), 176. https://doi.org/10.5539/jel.v5n1p176

Ali, M, M., Gulzar, A., \& Anwar, M, N. (2018). Impact of MALL on Grammar of EFL Learners in Pakistan. ELF Annual Research Journal, 20, 39-55. 
Azli, W. U. A. W., Shah, P. M., \& Mohamad, M. (2018). Perception on the Usage of Mobile Assisted Language Learning (MALL) in English as a Second Language (ESL) Learning among Vocational College Students. Education, 9, 84-98. https://doi.org/10.4236/ce.2018.91008

Baleghizadeh, S., \& Oladrostam, E. (2011). The effect of mobile assisted language learning (MALL) on grammatical accuracy of EFL participants. MEXTESOL Journal, 34(2), 117-123. https://doi.org/10.7575/aiac.alls.v.7n.2p.76

Bertram, D. (2007). Likert Scales... are the meaning of life: CPSC 681-Topic Report. In International Conference on Competitive Manufacturing, Department of Industrial Engineering, University of Stellenbosch, South Africa.

Bicen, H. (2015). The Role of Social Learning Networks in Mobile Assisted Language Learning: Edmodo as a Case Study. J. UCS, 21(10), 1297-1306.

Buckenmayer, J. (2011). Revisiting teacher adoption of technology: Research implications and recommendations for successful technology integration. College Teaching Methods and Styles Journal, 4(6), 7-10. https://doi.org/10.19030/ctms.v4i6.5554

Burston, J. (2013). Mobile-Assisted Language Learning: A Selected Annotated Bibliography.

Chang, C. K., \& Hsu, C. K. (2011). A mobile-assisted synchronously collaborative translation-annotation system for English as a foreign language (EFL) reading comprehension. Computer Assisted Language Learning, 24, 155-180. https://doi.org/10.1080/09588221.2010.536952

Chen, C. M., \& Hsu, S.-H. (2008). Personalized Intelligent Mobile Learning System for Supporting Effective English Learning. Educational Technology \& Society, 11(3), 153-180.

Chen, I.-J., \& Chang, C. C. (2011). Content presentation modes in mobile listening tasks: English proficiency as a moderator. Computer Assisted Language Learning, 24, 451-470. https://doi.org/10.1080/09588221.2011.577749

Colpaert, J. (2004). From courseware to coursewear? Computer Assisted Language Learning, 17(3-4), 261-266. https://doi.org/10.1080/0958822042000319575

Dehkordi, M. E., \& Taki, S. (2018). Iranian Male and Female EFL Learners' Perceptions toward the Use of Mobile Assisted Language Learning. Journal of Applied Linguistics and Language Research, 5(3), 56-66.

Downes, S. (2007). Learning networks in practice. In D. Ley (Ed.), Emerging technologies for learning (pp. 1927). Coventry, UK: Becta.

Evans-Cowley, J., \& Hollander, J. (2010). The new generation of public participation: Internet-based participation tools. Planning Practice \& Research, 25(3), 397-408. https://doi.org/10.1080/02697459.2010.503432

Fallahkhair, S., Pemberton, L., \& Griffiths, R. (2007). Development of a cross-platform ubiquitous language learning service via mobile phone and interactive television. Journal of Computer Assisted Learning, 23, 321-325. https://doi.org/10.1111/j.1365-2729.2007.00236.x

Garrison, D. R., Anderson, T., \& Archer, W. (2003). A theory of critical inquiry in online distance education. Handbook of Distance Education, 1, 113-127.

Hazaea, A., \& Alzubi, A. (2018). Impact of Mobile Assisted Language Learning on Learner Autonomy in EFL Reading Context. Journal of Language and Education, 4(2), 48-58. https://doi.org/10.17323/2411-7390-2018-4-2-48-58

Huang, Y. M., Huang, Y. M., Huang, S. H., \& Lin, Y. T. (2012). A ubiquitous English vocabulary learning system: Evidence of active/passive attitudes vs. usefulness/ease-of-use. Computers \& Education, 58(1), 273-282. https://doi.org/10.1016/j.compedu.2011.08.008

Hwang, W. Y., Huang, Y. M., Shadiev, R., Wu, S. Y., \& Chen, S. L. (2014). Effects of using mobile devices on English listening diversity and speaking for EFL elementary students. Australasian Journal of Educational Technology, 30(5). https://doi.org/10.14742/ajet.237

Inkpen, K. M. (1999). Designing Handheld Technologies for Kids. Personal Technologies Journal, 3(1\&2), 8189. https://doi.org/10.1007/BF01305323

Johnson, A. M. (2005). The technology acceptance model and the decision to invest in information security (pp. 114-118). In Southern Association of Information Systems Conference. 
https://doi.org/10.1142/S179320680900060X

Joseph, S. R., \& Uther, M. (2009). Mobile devices for language learning: Multimedia approaches. Research and Practice in Technology Enhanced Learning, 4(1), 7-32. https://doi.org/10.4018/IJMBL.2017010104

Kim, D., Ruecker, D., \& Kim, D. J. (2017). Mobile Assisted Language Learning Experiences. International Journal of Mobile and Blended Learning, 9(1). https://doi.org/10.4018/IJMBL.2017010104

Kukulska-Hulme, A. (2009). Will mobile learning change language learning? ReCALL, 21(2), 157-165. https://doi.org/10.1017/S0958344009000202

Kukulska-Hulme, A., \& Shield, L. (2008). An overview of mobile assisted language learning: From content delivery to supported collaboration and interaction. ReCALL, 20(3), 271-289. https://doi.org/10.1017/S0958344008000335

Lave, J., \& Wenger, E. (1991). Situated learning: legitimate peripheral participation. Cambridge: Cambridge University Press. https://doi.org/10.1017/CBO9780511815355

Lu, J., Yu, C. S., Liu, C., \& Yao, J. E. (2003). Technology acceptance model for wireless Internet. Internet Research, 13(3), 206-222. https://doi.org/10.1108/10662240310478222

McKinsey \& Company. (2017). Transforming learning through m-Education. Retrieved August 11, 2018, from http://www.mckinsey.com/ /media/mckinsey/industries/social\%20sector/our\%20insights/transforming\%201 earning\%20through\%20meducation/transforming-learning-through-meducation-final.ashx

Miangah, T. M., \& Nezarat, A. (2012). Mobile-assisted language learning. International Journal of Distributed and Parallel Systems, 3(1), 309. https://doi.org/10.5121/ijdps.2012.3126

Miettinen, K. (1999). Nonlinear multiobjective optimization. Kluwer, Boston. https://doi.org/10.1007/978-1-4615-5563-6

Mifsud, L. (2002). Alternative learning arenas-pedagogical challenges to mobile learning technology in education (pp. 112-116). IEEE International Workshop on Wireless and Mobile Technologies in Education, 2002. Proceedings. https://doi.org/10.1109/WMTE.2002.1039231

Moss, N. D., O'Connor, E. L., \& White, K. M. (2010). Psychosocial predictors of the use of enhanced podcasting in student learning. Computers in Human Behavior, 26(3), 302-309. https://doi.org/10.1016/j.chb.2009.10.012

Oz, H. (2015). An Investigation of Preservice English Teachers' Perceptions of Mobile Assisted Language Learning. English Language Teaching, 8(2), 22-34. https://doi.org/10.5539/elt.v8n2p22

Palalas, A. (2011). Mobile-assisted language learning: Designing for your students. Second language teaching and learning with technology: views of emergent researchers, 71-94. https://doi.org/10.14705/rpnet.2011.000007

Pintrich, P. R., \& Schunk, D. H. (2002). Motivation in education: Theory, research, and applications. Englewood Cliffs, NJ: Merrill/Prentice-Hall.

Rosell-Aguilar, F. (2007). Top of the pods-in search of a podcasting "podagogy" for language learning, Computer Assisted Language Learning, 20, 471-492. https://doi.org/10.1080/09588220701746047

Sandberg, K. W., \& Wahlberg, O. (2007). Towards a model of the acceptance of information and communication technology in rural small businesses. Department of Information Technology and Media, Mid Sweden University, SE-851, 70.

Sharples, M. (2005). Learning as Conversation: Transforming Education in the Mobile Age (pp. 147-152). In Proceedings of Conference on Seeing, Understanding, Learning in the Mobile Age. Budapest, Hungary.

Siddique, M. (2017). The effects of utilizing smartphone in enhancing students' English writing skills in Pakistan. Doctoral dissertation, University Utara Malaysia.

Siemens, G. (2007). Connectivism: Creating a learning ecology in distributed environments. In T. Hug (Ed.), Didactics of microlearning: Concepts, discourses and examples Munster.

Stockwell, G. (2007). Vocabulary on the move: Investigating an intelligent mobile phone-based vocabulary tutor. Computer Assisted Language Learning, 20(4), 365-383. https://doi.org/10.1080/09588220701745817

Surina, N., \& Kamaruzaman, J. (2009). A study of subject-verb agreement: From novice writers to expert writers. International Education Studies, 2(3), 190-194. https://doi.org/10.5539/ies.v2n3p190 
Tayan, B. M. (2017). Students and teachers' perceptions into the viability of mobile technology implementation to support language learning for first year business students in a Middle Eastern university. International Journal of Education and Literacy Studies, 5(2), 74-83. https://doi.org/10.7575/aiac.ijels.v.5n.2p.74

Teo, T., Lee, C. B., \& Chai, C. S. (2008). Understanding pre-service teachers' computer attitudes: Applying and extending the Technology Acceptance Model (TAM). Journal of Computer Assisted Learning, 24(2), 128 143. https://doi.org/10.1111/j.1365-2729.2007.00247.x

Trinder, J. (2005). Mobile technologies and systems. In A. Kukulska-Hulme \& J. Traxler (Eds.), Mobile learning: A handbook for educators and trainers (pp. 7-24). London: Routledge.

Van der Heijden, H. (2003). Factors influencing the usage of websites: the case of a generic portal in The Netherlands. Information \& Management, 40(6), 541-549. https://doi.org/10.1016/s0378-7206(02)00079-4

Viberg, O., \& Grönlund, A. (2012). Mobile assisted language learning: A literature review. In 11th World Conference on Mobile and Contextual Learning.

Vygotsky, L. S. (1978). Mind in society: the development of higher psychological processes. Cambridge: Harvard University Press.

Wang, Y., Buermann, W., Stenberg, P., Smolander, H., Häme, T., Tian, Y., ... \& Myneni, R. B. (2003). A new parameterization of canopy spectral response to incident solar radiation: Case study with hyperspectral data from pine dominant forest. Remote Sensing of Environment, 85(3), 304-315. https://doi.org/10.1016/s0034-4257(03)00009-9

Zaki, A. A., \& Yunus, M. M. (2015). Potential of Mobile Learning in Teaching of ESL Academic Writing. English Language Teaching, 8(6), 11-19. https://doi.org/10.5539/elt.v8n6p11

\section{Copyrights}

Copyright for this article is retained by the author, with first publication rights granted to the journal.

This is an open-access article distributed under the terms and conditions of the Creative Commons Attribution license (http://creativecommons.org/licenses/by/4.0/). 